\title{
Daturastramoniumpollen and it's possible role in allergenic etiology- Recommendations for standardization of pollen extracts for ASIT
}

\author{
BarnaliBera, SanjuktaMondal (Parui), Jayanta Kumar Kundu*, \\ Amal Kumar Mondal* \\ Post Graduate Department of Zoology, Lady Brabourne College, P 1/2 Suhrawardy Avenue, Kolkata-700017 \\ *Department of Zoology, Vidyasagar University, Midnapore-721102, West Bengal, India \\ *Plant Taxonomy, Biosystematics and Molecular Taxonomy Laboratory, UGC-DRS-SAP and DBT-BOOST- \\ Department, Department of Botany and Forestry Vidyasagar University, Midnapore-721102, West Bengal, \\ India
}

\begin{abstract}
DaturastramoniumL., a less known species of Daturais generally confused with its other related species Daturametel, the pollen of which has been proved to be allergenic. But D. stramoniumhas been found to grow luxuriantly in several places of West Bengal. There are still no reports on the allergenicity of the pollen of this plant. The present paper reports the pollen morphology and protein profile of the pollen of D. stramoniumat different stages of maturity. The pollen was collected both before and after anthesis and the change in protein profile and concentration studied for both immature (before anthesis) and mature (after anthesis) stages. A slight decrease in protein concentration was observed in case of immature pollen. The SDS-PAGE protein profile showed a total of 10 protein bands designated as D'1 to D'10, between the molecular weight range of 22 $k D a$ to $205 \mathrm{kDa}$. There was also a variation in the protein profile between immature and mature pollen with the number of protein bands being more in case of mature pollen. On the basis of ultrastructure studies, the pollen grains were found to be radially symmetrical, tricolporate, 3zonoaperturate and trichotomusculte with thick exine. Tectum is usually reticulate, striated with thick columella. Theexine pattern shows the presence of a thick columella.
\end{abstract}

Keywords: Daturastramonium, immature and mature pollen, SDS-PAGE, pollenmorphology

\section{Introduction}

"Hay fever" or allergenic rhinitis is one of the most important problems of human pathology all over the world. Clinically, hayfever is characterized by sneezing, rhinorrhea, obstruction of the nasal passages, conjunctival and pharyngeal itching and lacrimation. Although commonly seasonal, because of its relation to airborne pollen, other patterns and etiologies occur. With the view of significance of pollen antigens in diagnosis and therapy for allergenic patients, identification, isolation, purification and characterization of pollen allergens is a prerequisite for proper standardization. Antigen-specific immunotherapy is the only available curative treatment against allergic rhinitis. Subcutaneous injection of allergens with or without adjuvant has been commonly used in immunotherapy. However, recently, sublingual administration has come to be considered a safer and convenient alternative administration route of allergens. For immunotherapy, extracts from an allergen source, i.e. pollen extract, are widely used after the concentration of their major allergen is adjusted so as to be standardized. To standardize such extracts, it is important to analyze their component allergens and establish a quantification system for major allergens (American Academy of Allergy, Asthma and Immunology, 1997). Most extracts used in clinical practice are rather crude substances containing much extraneous material. To improve the safety and clinical therapeutic effects of a vaccine, the selection of allergens for vaccination is an important issue.Isolation and identification of the active allergenic components are critically needed information which could lead to elaboration of the fundamental nature of the atopic reaction and availability of more effective clinical therapeutic agents. The World Allergy Organization (WAO) recommends that standardized vaccines be used for immunotherapy if they are available. However, the protocols and methods for the standardization of allergen extract are different among different suppliers, which use their own in-house reference materials and their own unique allergen units. This makes it difficult to compare the therapeutic effects and safety among clinical trials involving different products. It has been proposed that vaccines be standardized using a protocol based on mass units of major allergens and that the active ingredients of the treatment be quantified (Fujimura and Okamoto, 2010). Efforts are being made globally to standardize the pollen antigens as pollen collected from different source materials, stages of maturity, time intervals and geographical places or with different storage periods have shown significant variation in their allergenic components (Singh et al., 1993). 
Daturastramonium L. also known as jimson weed is an annual herb which grows upto the height of 5 feet. The leaves are ovate, green or purplish, toothed and irregularly undulated.Itflowers throughout the summer. The flowers are pleasantly smelled, trumpet-shaped, white to creamy or violet, and 6 to $9 \mathrm{~cm}\left(2 \frac{1}{2}-3 \frac{1}{2}\right.$ in) long, and grow on short stems from either the axils of the leaves or the places where the branches fork.

Datura is one of the plant of God in India and used extensively by Indian people to worship Lord Shiva and are found to be sold in roadside flower stalls. The pollen of this plant has still not been considered as anallergenic hazard largely because of its entomophilous nature. In the history of pollen allergy greater attention hasbeen given by the aerobiologists to the plants which are anemophilous in nature. Consequently it is neglected in the routine aeropalynological surveys because of their rare occurrence. But contrary to this belief, surveys have reported the presence of entomophilous pollen from the airspora(Agashe, 1989; Agashe et al., 1983, Atluri et al., 1992; Singh and Babu, 1982; Singh and Devi, 1992; etc.).Moreover pollen grains are largely distributed in dense concentrations around their sources and therefore tend to be of local occurrence (Gregory, 1961). This is seen more in case of entomophilous pollen, which remain in high concentrations in air near the sourceplants (Durham, 1947).The pollen of Datura has been reported in the air by several workers (Santra et al., 1991; Jain et al., 1992) and its allergenic potency proved (Santra et al., 1991; Jain et al., 1992; Parui and Mandal, 1998).

Daturastramonium pollen has still not been reported allergenic but with the interspecific relationship of this species with Daturametel, the pollen of whichhas been proved to be allergenic,there always remains a possibility of the pollen of this plant to be also prevalent in the atmosphere and responsible for inducing the allergenic reactions in sensitive patients. Being dominant and growing luxuriantly in certain parts of West Bengal where the flower is used for worship mostly by females, it may be difficult to evade the pollen of this plant for sensitive patients. Moreover, the different species of Daturaare found to flower round the year and the people sensitive to the pollen of this plant have very little chance to avoid this allergen.

Pollen morphology plays an important role in the identification of the plant taxa to which an airborne pollen belongs to i.e. the mother plants. This is very important as lack of sufficient knowledge in the palynology of the present day plants can lead to erroneous identification of airborne pollen, subsequently leading to wrong interpretation or diagnosis of a patient's symptoms. The circumscription and taxonomic relationships between very similar species has been sometimes controversial. Along with other characters, the differences in pollen grain wall structure and exine ornamentation (sculpture) are found to be valuable characteristics for distinguishing between such species.

The present paper reports the pollen morphology of Daturastramonium and the comparative protein profile of the pollen of D.stramoniumat different stages of maturity. The variation in protein concentration has also beenanalyzed during different seasons. A comparative study of the data with that of Daturametel has also been made.

\section{Pollen collection}

\section{Materials And Methods}

Pollen grains of Daturastramonium were collected in bulk from the plants growing in South Calcutta, West Bengal. Two types of pollen were collected - one from mature buds and the other from flowers which had finished blooming on the same day as well as different days of different seasons. Pollen grains from the anthers were sieved using different meshes $(100,200$ and $300 \mu \mathrm{m})$. All the samples were analyzed under the microscope, to ensure pollen purity varying from $90 \%$ to $95 \%$.

\section{Light Microscopic Study}

The pollen samples were prepared by acetolysis method of Erdtman (1960). Duplicates from each type were prepared and 6 slides of each were made. L.M micrograph and measurements were taken using Nikon HFX-11 microscope using ocular micrometer scale by glycerine jelly method.

\section{Scanning Electron Microscopic study}

Properly dried pollen samples were mounted on stubs and sputter coated with gold. For observation a Zeiss Scanning Electron Microscope was used at $5 \mathrm{k}$.V. at the Central Research Facility Unit of IIT Kharagpur, West Bengal.

\section{Protein extraction}

Proteins from pollen were extracted according to the method of Singh et al. (1993) with slight modifications (Mondal et al. 1997). The pollen was defatted with cold solvent ether and then dried in vacuum desiccators. The defatted pollen was then used for protein extraction. Proteins were extracted in $0.2 \mathrm{M} \mathrm{TrisHCl}$ buffer ( $\mathrm{pH} 7.4$ ) by continuous stirring at $4^{\circ} \mathrm{C}$ for $20 \mathrm{~h}$. The extract was clarified by centrifugation at $12000 \times \mathrm{g}$ for 5 minutes at $4^{0} \mathrm{C}$. The supernatant was collected. The samples were then stored at $-20^{\circ} \mathrm{C}$. 


\section{Estimation of proteins}

The protein concentration in the extract was estimated by the modified method of Lowry (Lowry et al., 1951). A calibrated solution of bovine serum albumin was used as a standard.

\section{Gel electrophoresis}

The protein sample was heated with an equal amount of sample buffer [0.06M TrisHCl (pH 6.8), 1\% SDS, $10 \%$ sucrose, $0.5 \% \beta$-mercaptoethanol, $0.01 \%$ Bromophenol blue] at $100^{\circ} \mathrm{C}$ for 3 min. The sample was loaded in the well of a $10 \%$ T mini-gel $(8 \times 7 \mathrm{~cm}$ gel) and the gel was run using Laemmli buffer system (1970) [0.05 M Tris, $0.192 \mathrm{M}$ Glycine, 0.1\% SDS, $\mathrm{pH} 8.4$ ] at room temperature for $2 \mathrm{hrs} 30 \mathrm{~min}$ at $70 \mathrm{~V}$. The gel was calibrated using a marker mixture consisting of Myosin, Rabbit Muscle (205 kDa), Phosphorylase b (97.4 kDa), Bovine Serum Albumin (66 kDa), Ovalbumin (43 kDa), Carbonic Anhydrase (29 kDa) and Soyabean Trypsin Inhibitor $(20.1 \mathrm{kDa})$. After electrophoresis, the gel was stained with $0.1 \%$ Coomassie Brilliant Blue R 250 and destained with methanol: acetic acid: water (4:1:5) mixture.

\section{Results And Discussion}

Daturastramonium pollen is characterized by Tricolporatepollen grains which is a characteristic of the familySolanaceae to which Datura belongs. It can be recognized by its tectum type which is striate at mesocolpium with distinct perforations in between the larie. The ornamentation is coarsely reticulate regulate towards apocolpium region and theluminais characterized with columella. The ultrastructure of the trichomusculatepollen of Daturastramonium revealed the tricolporate and zonoaperturate nature as reported by other investigators.

Polar (P) and equatorial measurements of pollen grains were generally of larger dimensions for Datura sp. unlike other species of Solanaceae. The pollen outline of Daturastramoniumis elliptical in equatorial view while the polar view is spherical. The pollen exhibited a lesser reticulate exine pattern. Lesser perforations were observed in polar view. Columellais thick at sexine.Exine is more reticulate at apocolpium in case of $D$. metelwith less prominent columella.

The protein concentration showed a variation between immature and mature pollen. It was found to be higher in case of mature pollen than the immature one. The protein concentration of mature and immature pollen of Daturastramonium was found to be $162 \mu \mathrm{g} / \mathrm{ml}$ and $127 \mu \mathrm{g} / \mathrm{ml}$ respectively.

The SDS-PAGE protein profile of the pollen showed 10 protein bands designated as D'1 to D'10 ranging between the molecular weight range of $21.2 \mathrm{kDa}$ to $205 \mathrm{kDa}$. There was also a variation in the protein profile between immature and mature pollen. The number of protein bands in case of mature pollen (9) was greater than that observed in case of immature pollen (8). Nine bands were observed in case of mature pollen with two protein bands viz. $48.8 \mathrm{kDa}$ and $21.2 \mathrm{kDa}$, absent in case of immature pollen while immature pollen showed eight bands with a $54.5 \mathrm{kDa}$ protein absent in case of mature pollen. Seven bands were common in both mature and immature pollen. A considerable homology was observed in the protein profile of the pollen of DaturastramoniumandDaturametel.Five of the bands (205 kDa, 97.4 kDa, $87 \mathrm{kDa}, 43 \mathrm{kDaand} 29 \mathrm{kDa})$ were also found in the pollen of Daturametel(Bera et al., 2015).

\section{Conclusion}

Daturastramoniumwhich is still not reported to produce allergenic pollen shows close resemblance to the pollen of the allergenic species ofDaturametelboth morphologically as well as in protein profile and is known to contribute significantly to air-spora. Thus $D$. stramoniumalthough of typical entomophilous nature shows the necessity to evaluate the nature of this entomophilous pollen in proper perspective as they too contribute significantly to the air-spora and release appreciable amount of pollen which subsequently become airborne especially close to the source and may be a matter of great concern to a sensitive individual who might show pronounced allergenic reactions to Datura sp. (Tilak, 1989). According to Tilak (1989), concentration of entomophilous airborne pollen under favourable conditions during anthesis would vary from zero to real appreciable number. The exine pattern and tricolporate nature of pollen also indicate their presence in air in large numbers which may prove to be a potential risk to the sensitive patients. Further, the variation in the protein content as well as the profile with the different stages of maturity shows the need for proper standardization of the pollen extracts and designing standardized immunotherapic vaccines for effective allergen specific immunotherapy (AIT).

\section{Acknowledgements}

The authors are indebted to UGC, New Delhi for financial assistance in the form of a Major Research Project [Ref. No. F. No. 42-559/2013 (SR) dated 22.03.13]. 


\section{References}

[1] Agashe, S.N., Anand, P., Manjunath, K. and Abraham, J.N. (1983). Airborne pollen survey at Bangalore (A preliminary study). Asp. Allergy \& Appl. Immunol.,16 : 53-57.

[2] Agashe, S.N. (1989). Airborne entomophilous pollen - potential source of allergy. -In: Recent Researches in Ecology, Environment and Pollution (ed. Tilak, S.T.), Today \& Tomorrow's Printers and Publishers, New Delhi, Vol.3, pp.153-157.

[3] American Academy of Allergy, Asthma and Immunology (1997). The use of standardized allergen extracts. American Academy of Allergy, Asthma and Immunology (AAAAI). J Allergy Clin.Immunol., 99: 583-586.

[4] Atluri, J.B., NarayanaRao, K.V.V. and Ramachandraiah, M. (1992). Site to site variations in airborne pollen grains in Visakhapatnam. Ind. J. Aerobiol., Special Volume, pp.29-36.

[5] Bera, B., Mondal (Parui), S. and Mondal, A.K. (2015). Variation in the protein profile of the allergenic pollen of Daturametel with different stages of maturity. International Journal of Current Research, 7(6): 17174-17180.

[6] Durham, D.C. (1947). The volumetric incidence of atmospheric allergens. Spot testing in evaluation of species. J. Allergy, 18: 231238.

[7] Erdtman, G., 1960. The acetolysis method, a revised description, seven. Bot. Tidsker, 54: 561-564.

[8] Fujimura, T. and Okamoto, Y. (2010). Antigen-Specific Immunotherapy against Allergic Rhinitis: The State of the Art. Allergology International, 59: 21-31.

[9] Gregory, P.H. (1961). The Microbiology of the Atmosphere. 1st ed. Wiley Interscience, New York, p.251.

[10] Jain, A.K., Patel, P. and Datta, T.R. (1992). Production, dispersion and sensitivity of some allergenic pollen grains at Gwalior. Ind. J. Aerobiol., Special Volume, pp.95-98.

[11] Laemmli, U. K. (1970). Nature, 227: 680

[12] Lowry, C.H., Rosebrough, N.J., Farr, A.L. and Randall, R.I. (1951). Protein measurement with folin phenol reagent. J.Biol. Chem., 193: $265-275$

[13] Mondal, A.K., S. Parui, S.R. Biswas and S. Mandal. "Identification of the allergenic proteins of Ipomoea fistulosaL. pollen: Partial characterization and sensitivity test”. Grana, 36(1997): 301-305.

[14] Parui, S. and Mandal, S. (1998). Biochemical analysis and skin sensitivity test of the allergenic pollen of Daturametel L. Current Science, 74(1): 66-68.

[15] Santra, S.C., Gupta, S. and Chanda, S. (1991). Air pollutants and aeroallergens interaction. Grana, 30: 63-66.

[16] Singh, A.B. and Babu, C.R. (1982). Survey of atmospheric pollen allergens in Delhi: seasonal periodicity. Ann. Allergy, 48: 115122.

[17] Singh, N.I. and Devi, K.K. (1992). Aerobiology and allergic human diseases in Manipur II. Airborne pollen grains of Imphal, Imphal District. Ind. J. Aerobiol., Special Volume, pp.37-42.

[18] Singh, A.B., P. Malik, D. Prakash. and S.V. Ganga, "Identification of specific IgE binding proteins in Castor bean (Ricinuscommunis) pollen obtained from different source materials." Grana, 31(1993): 376- 380.

[19] Tilak, S.T. (1989). Airborne pollen \& fungal spores. Vaijayanti Prakashan, Aurangabad.

\section{Legends to figures:}

Fig. 1 (A\&B): The plant of Daturastramoniumin full bloom.

Fig. 2: Light Microscopicimages of pollen of Daturastramonium

Fig.3 (A-F): LM and SEM image of Daturastramonium showing 100\% pollen purity.

Fig. 4: SEM images of pollen of D. stramonium: A- Polar view of pollen of D. stramonium; B- Exine pattern in polar view; C- Equatorial view of pollen of D. stramonium;D- Exine pattern in equatorial view; E- Pollen showing furrow; F- Pollen showing trichotomusculature;

Fig. 5: SDS-PAGE protein profile of the pollen of immature pollen of Daturastramonium (a), (b)\& (C) $15 \mu 1,10$ $\mu l$ and $5 \mu 1$ of protein sample respectively.

Fig. 6: SDS-PAGE protein profile of the pollen of mature pollen of Daturastramonium(a) BSA (66 kDa) marker (b) molecular weight marker (c) \& (d) $40 \mu 1$ and $20 \mu 1$ of protein sample

Fig.7: Diagrammatic representation of the protein profile of the pollen of Daturastramonium(a) Molecular weight markers (b) mature pollen (c) immature pollen.

Table 1: Protein concentration in the pollen of Daturastramonium

\begin{tabular}{|c|c|}
\hline $\begin{array}{c}\text { PROTEIN CONCENTRATION IN IMMATURE } \\
\text { POLLEN }\end{array}$ & PROTEIN CONCENTRATION IN MATURE POLLEN \\
\hline $127 \mathrm{ugm} / \mathrm{ml}$ & $162 \mathrm{ugm} / \mathrm{ml}$ \\
\hline
\end{tabular}

Table 2: SDS-PAGE protein profile of the pollen of Daturastramonium

\begin{tabular}{|c|c|c|c|c|}
\hline \multirow{2}{*}{$\begin{array}{c}\text { M.W of Marker } \\
\text { Proteins (kDa) }\end{array}$} & \multicolumn{2}{|c|}{ Proteins bands of Immature pollen } & \multicolumn{2}{c|}{ Proteins bands of Mature Pollen } \\
\cline { 2 - 5 } & Protein band & M.W in(kDa) & Protein band & M.W in(kDa) \\
\hline 205 & D'1 & 205.0 & D'1 & 205.0 \\
\hline & D'2 & 133.3 & D'2 & 133.3 \\
\hline 97.4 & D'3 & 97.4 & D'3 & 87.4 \\
\hline & D'4 & 87.0 & D'4 & 74.9 \\
\hline & D'5 & 74.9 & - & - \\
\hline D'6 & 54.5 & - & - \\
\hline 43 & - & - & D'7 & 48.8 \\
\hline 29 & - & - & D'8 & 43.0 \\
\hline & D'8 & 43.0 & D'9 & 29.0 \\
\hline 20.1 & D'9 & 29.0 & D'10 & 21.2 \\
\hline 14.3 & - & - & - & - \\
\hline
\end{tabular}


Daturastramoniumpollen and it's possible role in allergenic etiology-Recommendations for

Table 3: The pollen of Daturastramonium showing pollen class measurements $\mathrm{P}$ (polar) and E(equatorial) views in $\mu \mathrm{m}$ with polar and equatorial ratios.

\begin{tabular}{|c|c|c|c|c|}
\hline Species & Pollen class & P(um) & E(um) & P/E \\
\hline Daturastramonium & Tricolporate, 3 Zonoaperturate & $40-45.5$ & $48.70-51.6$ & $0.82-0.88$ \\
\hline
\end{tabular}

Table 4:The pollen of Daturastramonium showing outline view: P- Polar; E- Equatorial; “+”- Present.

\begin{tabular}{|c|c|c|c|c|}
\hline Species & E & P & P/E & Trichotomusculate \\
\hline Daturastramonium & Elliptical & Circular & Subtransverse & + \\
\hline
\end{tabular}

Table 5: The pollen of Daturastramonium showing exoaperture and endoaperture structures.

\begin{tabular}{|c|c|c|c|c|c|c|}
\hline \multirow[t]{2}{*}{ Species } & \multicolumn{3}{|c|}{ Exoaperture } & \multicolumn{3}{|c|}{ Endoaperture } \\
\hline & Colpi & Fastigia & Margin & Colpi & Costae & Margins \\
\hline Daturastramonium & Small & - & Indistinct & Large & - & Indistinct \\
\hline
\end{tabular}

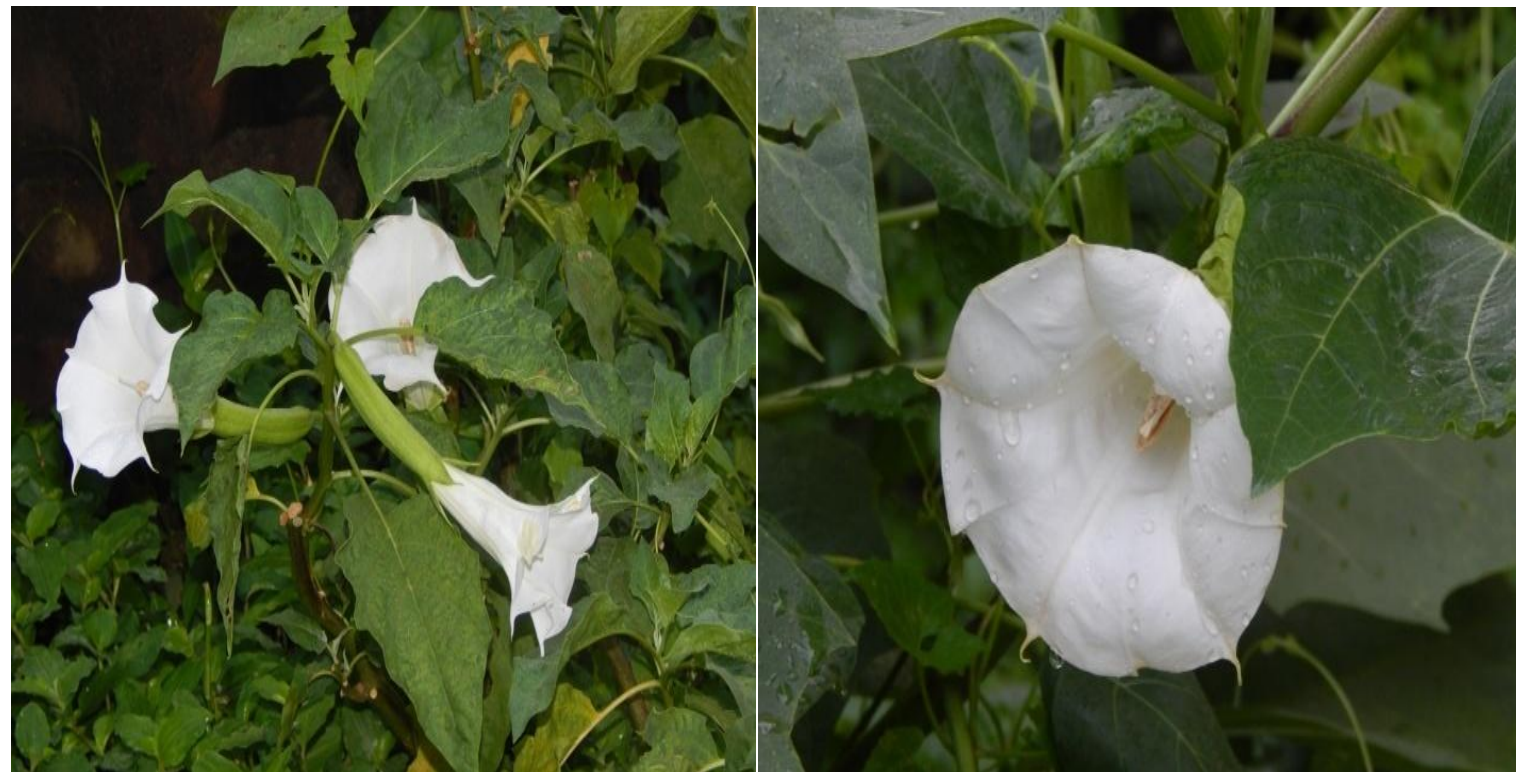

A

B

Fig:1

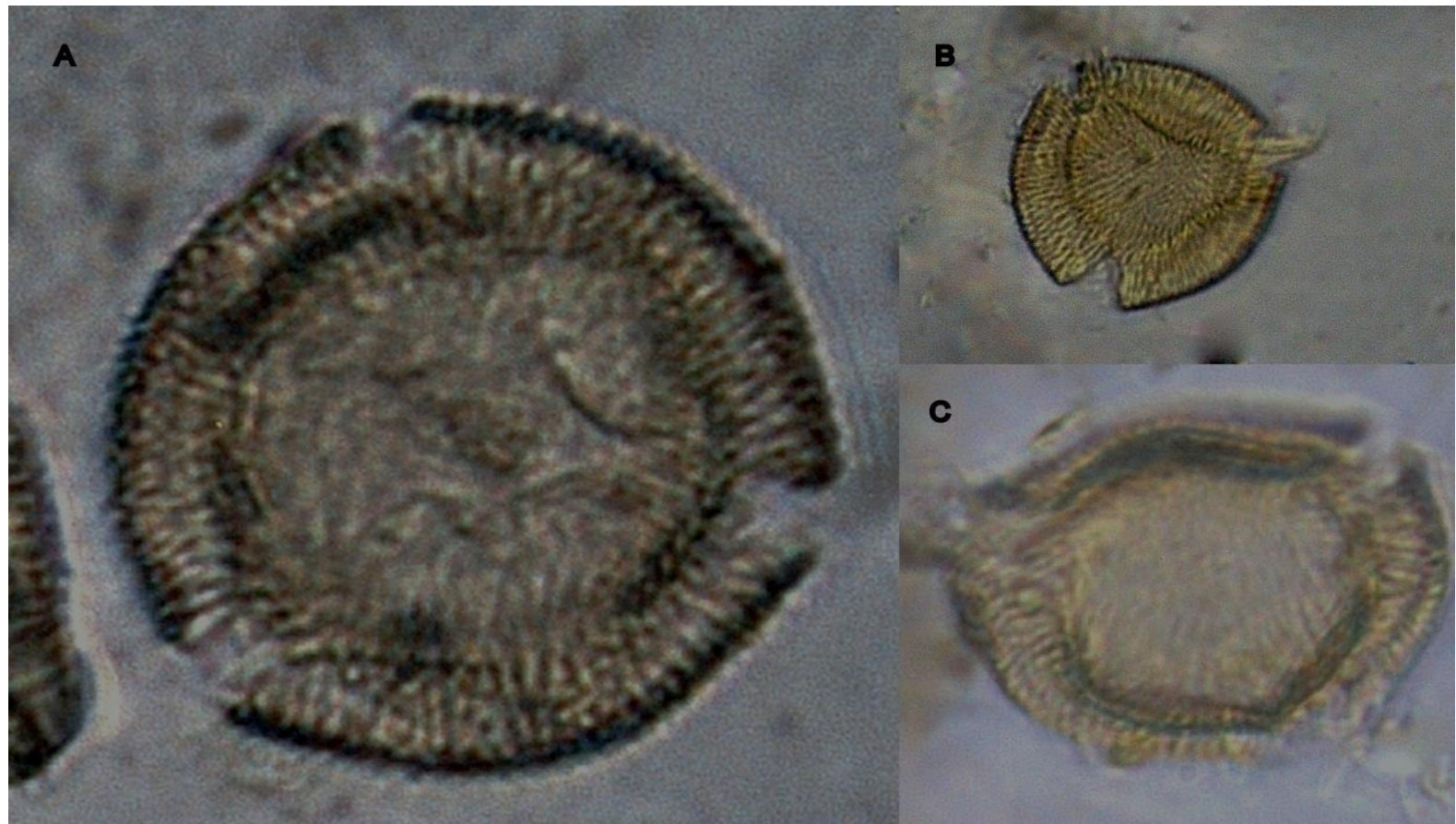

Fig:2 


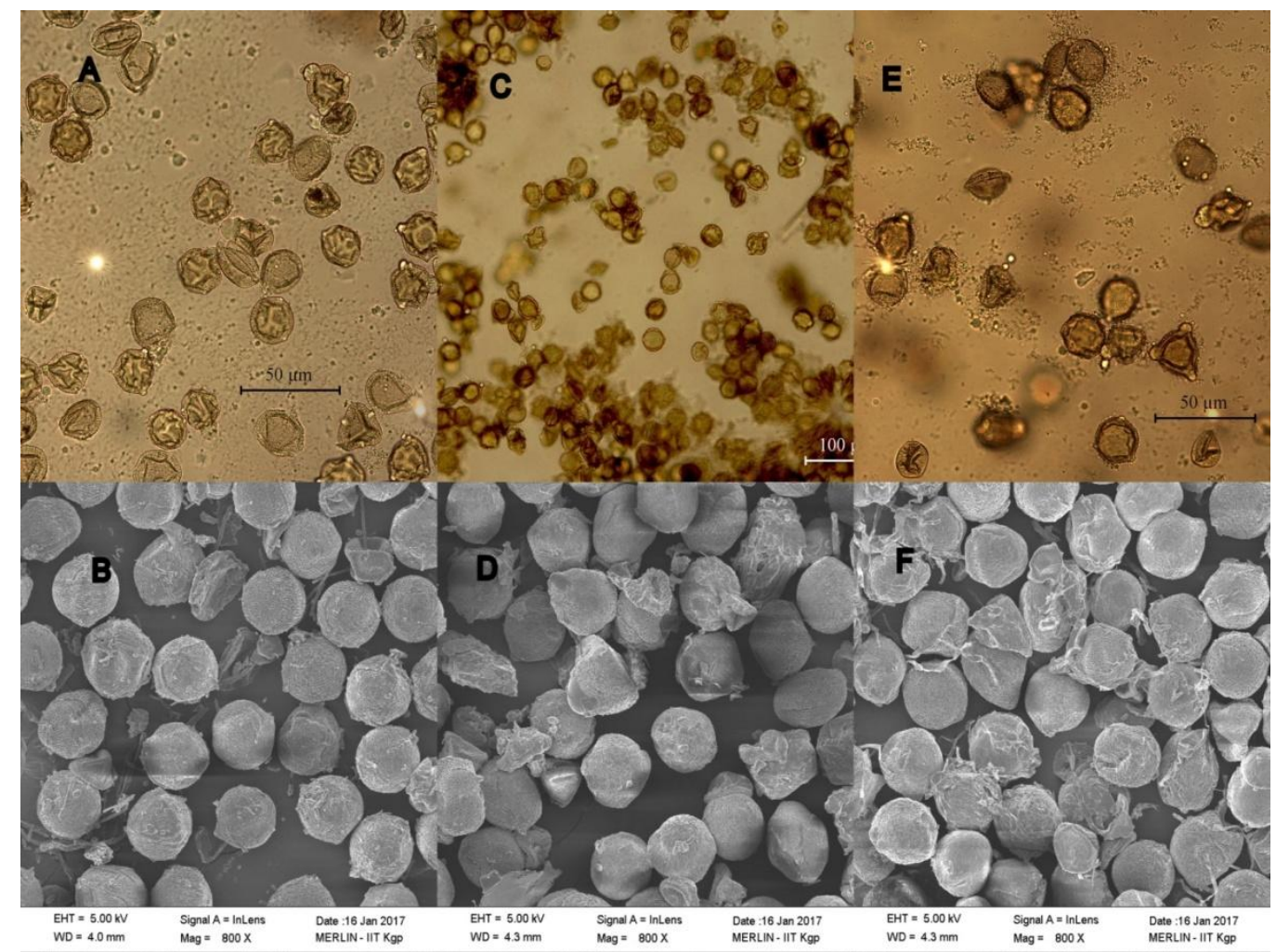

Fig: 3

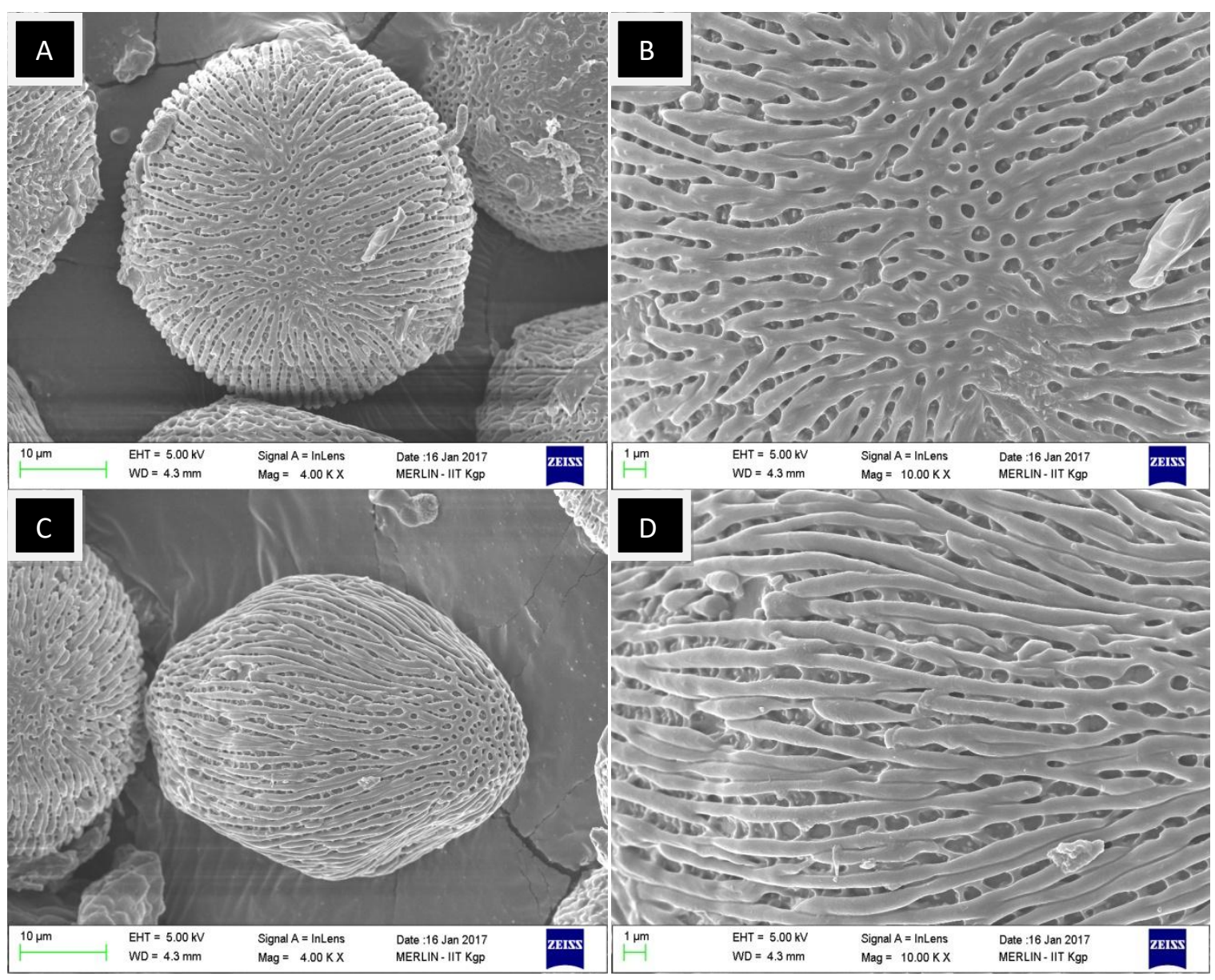


Daturastramoniumpollen and it's possible role in allergenic etiology-Recommendations for

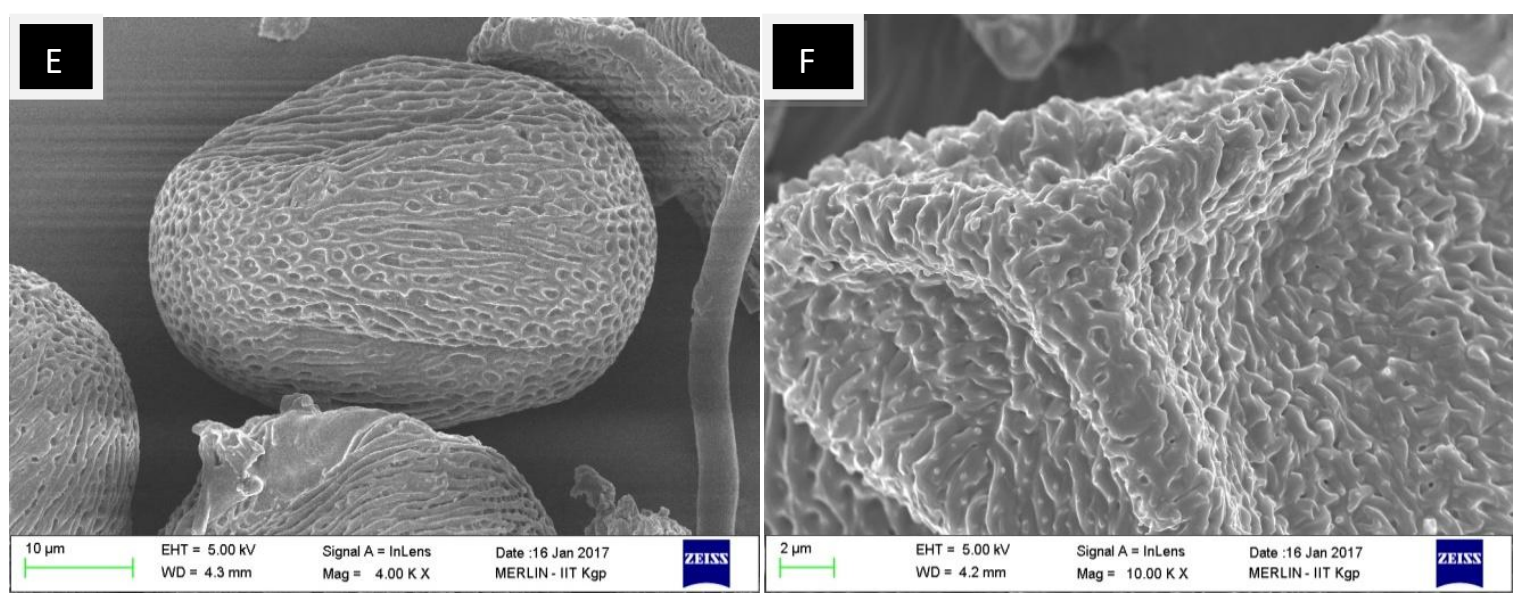

Fig: 4

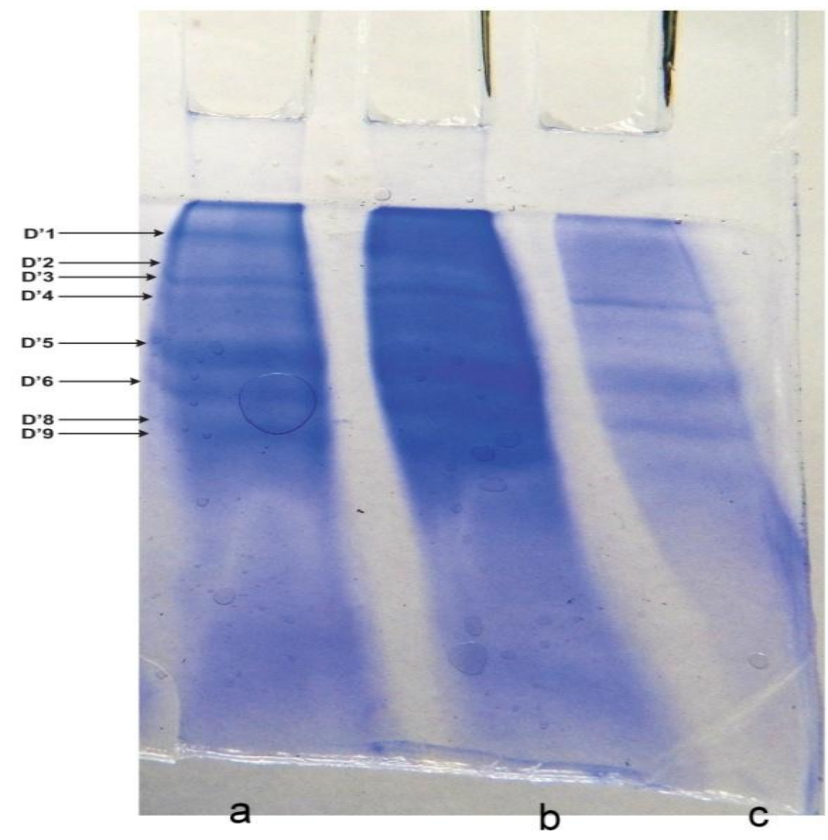

Fig. 5

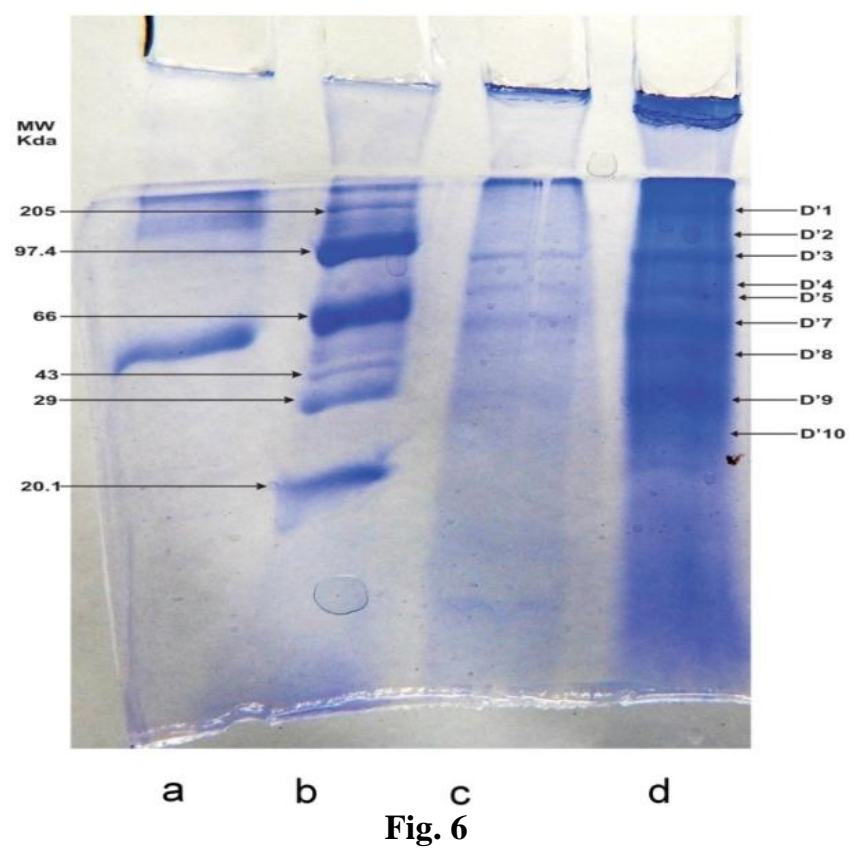




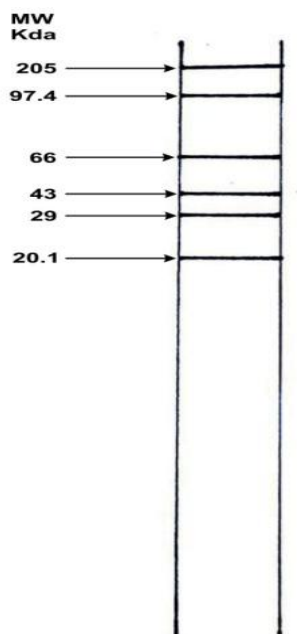

a

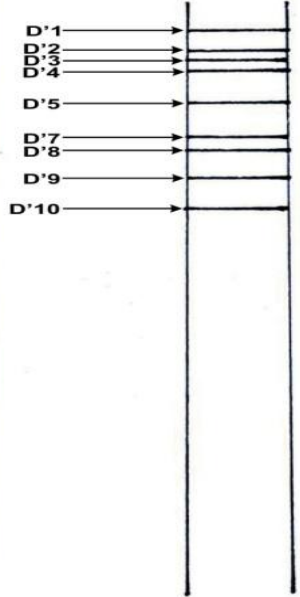

b

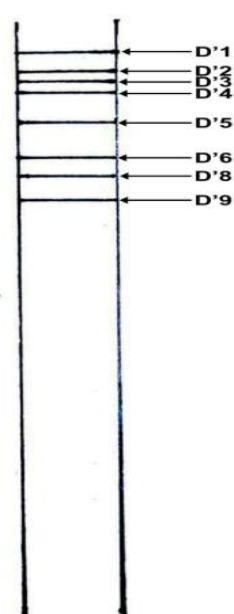

C

Fig. 7 